\title{
IMPROVEMENT ASSESSMENT OF MASTOLOGIST IN THE BREAST ONCOPLASTIC AND RECONSTRUCTIVE SURGERY OF SANTA CASA DE BELO HORIZONTE, MG, BRAZIL
}

\author{
Avaliação do aprimoramento do mastologista em cirurgia \\ oncoplástica e reconstrutiva da mama da Santa Casa de Belo Horizonte
}

Douglas de Miranda Pires', Carolina Lemos Baroncelli², Cicero de Andrade Urban³, Carolina Nazareth Valadares*, Mariana dos Santos Nascimentoํ, Izabel Aparecida Cunha Andrade

\section{ABSTRACT}

Objective: This study aims to investigate the efficacy and improvement of knowledge acquired by breast cancer specialists in a postgraduate course of Oncoplastic Surgery conducted in Santa Casa de Belo Horizonte (SCBH). Method: For this evaluation, an exploratory qualitative study was carried out. It was supported by an online survey questionnaire sent to 36 breast cancer specialists, who had taken the course in the period from 2012 to 2014. The data were interpreted using statistical methods, as well as probabilistic sampling. Results: After the Oncoplastic Surgery course, almost all breast cancer specialists who had taken it demonstrated the ability to reconstruct the breasts of women who had undergone mastectomies with oncoplastic techniques. A large portion of the specialists was able to develop bilateral treatment with breast reduction, mastopexy and rebuild areolas and nipples, as well as immediately reconstruct the breast with expanders or prosthesis and contralateral symmetrization. A significant amount of professionals was able to perform breast reconstruction with autologous flaps. Conclusion: The course for the Professional Development of Breast Cancer Specialists sponsored by the Teaching and Research Institute of Santa Casa de Belo Horizonte was able to improve the skills of the professionals involved in the different breast remodeling and reconstruction techniques. This enables a paradigm shift in the treatment of cancer patients.

KEYWORDS: Breast Cancer; Breast reconstruction; Breast diseases.

\section{RESUMO}

Objetivo: Este trabalho objetiva investigar a eficácia e aprimoramento dos conhecimentos adquiridos por mastologistas no Curso de Pós-graduação de Oncoplastia Mamária da Santa Casa de Belo Horizonte (SCBH). Método: Para essa avaliação, realizou-se um estudo exploratório de natureza qualitativa. Como suporte, a aplicação de questionário de pesquisa, enviado online aos trinta e seis mastologistas que fizeram o Curso, no período de 2012 a 2014. Os dados foram interpretados por intermédio de métodos estatísticos, bem como por uma amostragem probabilística. Resultados: Após o Curso, quase a totalidade dos Mastologistas que se aprimoraram se mostram capazes de reconstruir a mama das mulheres mastectomizadas com técnicas oncoplásticas. Uma grande parcela tem condições de desenvolver tratamento bilateral com redução mamária, mastopexia e reconstruir aréolas e mamilos, e reconstruir de maneira imediata a mama, com expansores ou próteses e simetrização contralateral. Uma quantidade significativa dos profissionais é capaz de efetuar a reconstrução da mama com retalhos autólogos. Conclusão: O Curso promovido por esse Instituto de Ensino e Pesquisa foi capaz de aprimorar os profissionais envolvidos, nas diferentes técnicas de remodelamento e reconstrução mamária. Isso possibilita uma mudança de paradigma no tratamento da paciente oncológica.

PALAVRAS-CHAVE: Câncer de mama; Reconstrução da mama; Doenças da mama.

Study carried out at Santa Casa de Belo Horizonte - Belo Horizonte (MG), Brazil.

${ }^{1}$ Mastology Clinic of Santa Casa de Belo Horizonte - Belo Horizonte (MG), Brazil.

${ }^{2}$ Teaching and Research Institute of Santa Casa de Belo Horizonte - Belo Horizonte (MG), Brazil.

${ }^{3}$ Universidade Positivo - Curitiba (PR), Brazil.

*Corresponding author: carolinanvaladares@gmail.com

Conflict of interests: nothing to declare.

Received on: 09/24/2016. Accepted on: 10/19/2017 


\section{INTRODUCTION}

According to the World Health Organization (WHO) ${ }^{1}$, a high incidence of cancer has been caused by a rapid change in the lifestyle of people in developing countries, which increasingly resemble those of industrialized countries. The increase in smoking and obesity rates, as well as in life expectancy also contribute to an increase in the number of breast cancer cases.

In Brazil, the cancer problem has become relevant because of the disease's epidemiological profile, thus entering into the political and technical agendas of all governmental spheres. Knowledge about cancer permits the establishment of priorities and the allocation of resources towards a positive change in the Brazilian population.

Excluding non-melanoma skin cancer, breast cancer is the second most common type in the world and is the most common among women, accounting for $22 \%$ of new cases each year. The highest occurrence of the disease among Brazilian women occurs in the Southeast region, where there are 64.54 cases $/ 100,000$ women. In the Southern region - 64.3/100,000 women; Midwestern region - 37.68/100,000 women; Northeastern region - 30.11/100,000 women; and Northern region, with the lowest incidence, 16.62/100,000 women. This data reflects a more industrialized society that has increasing consumption of unhealthy food, obesity, stress, sedentary lifestyles, alcohol consumption and a higher parity rate, or at least the beginning of these indices ${ }^{2}$.

Among the different situations and lesions, if mastectomy is required, the ideal solution is immediate breast reconstruction, since it can reduce the impact caused by this type of cancer. With the increase in overall survival of women with breast cancer, this alternative procedure is considered in such situations.

The evaluation of quality of life has become an increasingly used and valued parameter, and has guided the decisions of health professionals and patients with the most diverse diseases ${ }^{3}$. Aspects such as function, dysfunction, in addition to physical and emotional discomfort are relevant to the quality of life for a given function, population or symptom. Loss of the breast can cause devastating effects that include physical and psychic depreciation. Restorative surgery can increase the functional capacity and the psychological well-being of patients, especially with regard to self-esteem.

According to the Brazilian National Cancer Institute (Instituto Nacional do Câncer-INCA) ${ }^{4}$, Law No. 12.802/2013 requires that the Public Health System (Sistema Único de Saúde - SUS) perform restorative surgery on women who have had their breast removed due to cancer, and who show favorable clinical conditions. Also, Data from the Public Health System Database (Datasus, 2013) show that less than $10 \%$ of Brazilian patients who have undergone a mastectomy have access to immediate breast reconstruction through SUS ${ }^{4}$. This means that an immense majority of these women continue to have asymmetries and important aesthetic defects. In the country, the rates of immediate reconstruction are very low, although there is specific legislation that provides for the possibility of this surgery.
The main reason for delayed reconstruction is the lack of trained professionals to perform this type of surgery ${ }^{5}$.

Far from being a specialty or attribute, mammary oncoplasty is a set of surgical skills and techniques used for the purpose of providing patients with better aesthetic results without sacrificing oncological treatment (which must always come before aesthetics). It encompasses surgical techniques for breast reconstruction and remodeling that can be applied to both the cancerous and the contralateral breast ${ }^{6}$. Its use allows for a broad tumor approach, favors safe cancer margins, and can be an important tool in reducing the risks of compromised margins and reoperations ${ }^{7}$. The procedure is a technique to be learned, developed, elaborated on, and increasingly performed by breast cancer specialists in breast cancer treatments.

The purpose of the different Hands-on Breast Cancer Oncology courses, each of which has its own characteristics, is to improve the training of specialists so that they are more qualified. Their purpose is to guarantee comprehensive care in the treatment of this type of cancer, as well as to promote the importance of this reconstruction 8 .

It is assumed that a portion of these professionals does not have the inclination or opportunity to learn breast reconstruction techniques, and practice patterns will depend on local circumstances and available opinions. The SBM's Oncoplastic and Reconstructive Surgery Commission (2013-2016 triennium) defined that a specific certification in the field of Mastology is not necessary, but recommends that professionals who are interested in this surgical approach, and who have not had the opportunity to perform a more specific training, seek training in breast reconstruction techniques?

This study aims to investigate the applicability of the systematization of the improvement of breast cancer specialists who took the course in the period from 2012 to 2014, in Santa Casa de Belo Horizonte (SCBH). The article tries to generate factors that allow for the constant evaluation of the course's curricular material, especially in its more technically related contents. Furthermore, it aims to subsidize the decision-making process for changes, especially with respect to special topics that propose an offering of relevant content for practical improvement ${ }^{9}$.

Similar studies to this evaluation have already been published by other training centers in Mammary Oncology, such as Hospital Araújo Jorge in Goiânia and Hospital do Câncer de Barretos. Each of them points out the singularities and highlights of their courses and students ${ }^{10}$.

\section{METHODS AND MATERIALS}

For this evaluation, an exploratory, qualitative study was carried out ${ }^{11}$. According to Minayo, the qualitative view is the "locus where conflicts and compromises, traditions and changes, are articulated, and where everything has meaning, or meanings, 
since there is never anything human in meaning nor just one explanation for the phenomena they encompass" ${ }^{\prime 1}$. The qualitative analysis allows for the decoding of the content presented by the subjects of this study and translates their reality. According to Fontanella et al., "the testimonies of the subjects are understood as representing a segment of belonging" ${ }^{\prime 2}$. They go from "me" to "us".

In order to characterize the "life-rebuilding" activities of the women by the professionals who took the Oncology and Reconstructive Breast Surgery Improvement Course at SCBH, a quantitative data survey was chosen. The hypothesis here is not causal, but aims to verify if the perception and performance of professionals are in accordance with the reality investigated.

In this investigation, the research was conducted using a questionnaire survey with eleven multiple-choice questions. It was sent online to breast cancer specialists (thirty-six of them), who took the course in the mentioned period (Appendix 1). The aim was to identify their profile, how the practices are done in their different realities, and the possible shifts in paradigms in the treatment of cancer patients.

Multiple-choice questions have the following advantages: ease of application, processing and analysis, and quick response. They furthermore present little possibility of error. The disadvantages are that they require great care and preparation time to ensure that all response options are offered. If a major alternative option has not been previously included, strong biases may occur, even when the option for "other" and the question "which ones" are included. The respondent may be influenced by the options presented.

The questionnaire followed the prerogatives established in the study and had certain guiding principles from Moscarola ${ }^{13}$ (Figure 1), in which the measurement of the variables describes the characteristics of the sample.

In spite of the fact that the survey was clearly defined for professionals and there was adequate time between questions and feedback, 16 of them did not respond to the questions (44.4\%). This aspect was a limiting factor in the study.

Because it could affect the expected quality of the results, the possibility of developing a probabilistic (valid) sample, composed by the group of professionals that answered the survey,

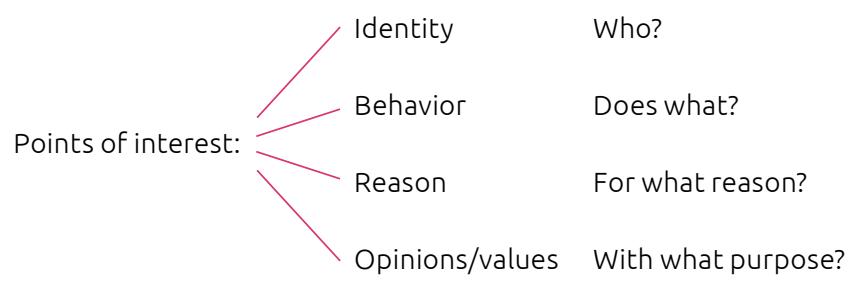

Source: Moscarola ${ }^{13}$.

Figure 1. The questionnaire as a list. was questioned. A valid sample is considered to be a representative subset of the target population.

\section{DISCUSSION}

For professionals who did not have specific training, the practical courses supported by SBM are an appropriate methodology to assist them in their practices.

The "Lato Sensu" Post-Graduate Course of Santa Casa de Belo Horizonte (SCBH) aims to "provide training and professional development in surgical procedures for breast remodeling after breast cancer surgery, techniques for breast reconstruction, corrective mastoplasty, and management of surgical intercurrences"

The course began as a medical extension program that had practical training in the operating room and covered various surgical procedures related to this type of remodeling. The initiative was successful, and from 2012 until today, it has been constituted as a "lato sensu" program. Similarly to other different courses at this particular educational institution, it adopts "a differentiated didactic/pedagogical methodology in relation to the other available courses"?.

In the training and professional development program organized by SCBH, in the period from 2012 to 2014, students had monthly classes with three teachers. Thirty-six doctors participated in the course, which made it possible to provide care for two hundred and ninety-three patients. Some of them underwent surgical procedures more than once, as there were cases in which two or three surgeries were necessary to complete the treatment.

For doctors who participate in this type of training, the Brazilian Society of Mastology (SBM) requires that they received the title of "specialist" from the institution.

In 2012, for the training and excellence of the professionals, the activities were presented in six modules with a total of 144 hours. In the period between 2013 and 2014, the workload was increased to 240 hours in a total of 10 modules. They were distributed as follows:

1. Oncoplastic Breast Surgery (24 hours);

2. Corrective mastoplasty (24 hours);

3. Dermoglandular patchwork (24 hours);

4. Review of techniques: refinement and management of complications (24 hours);

5. Breast Implants (24 hours);

6. Myocutaneous flaps (24 hours);

7. Myocutaneous flaps (24 hours);

8. Review and improvement of procedures (24 hours);

9. Alternative techniques (24 hours);

10. Refinement and management of complications (24 hours) 9 .

The course proposal for the years 2015 and 2016 consists of fifteen modules with a total of 540 hours. Similar to the courses offered in previous years, after completion of the professional 
development program, participants must be certified by the national SBM ${ }^{9}$.

The reflections are defined from the understanding of the potential (practical efficiency) of the professional development for the breast cancer specialists in the period from 2012 to 2014 in SCBH. Based upon this premise, it was possible to establish the survey, which evaluates the course from the point of view of professionals before and after its completion. Research, as Minayo states, "is a way to understand something holistically, even freeing it from disciplinary ties ${ }^{11}$."

Similar to Mizukami et al.'s research on the integration of scientific-pedagogical and personal knowledge ${ }^{14}$, it is understood that, from the analysis, the professionals specialized in this professional development can benefit from reflecting on its practices, learning to systematize their specific knowledge and become aware of theories that justify their decisions and attitudes in the real context of work. This knowledge is built in action and it explains "secret and sacred stories" 14 that reveal beliefs and hypotheses that guide their professional practices and question their convictions, allowing them to share their knowledge among peers. In the sense that the authors (2002) give to them, sacred histories are constituted of personal perceptions of practice and are related to theories shared by peers. As for the secrets, they correspond to the daily practices of the professionals. They are experienced without external judgment and are apparently disconnected from theoretical references. Through the revelation of the secret stories, tactical knowledge-oriented practices can be recognized $(2002)^{14}$.

According to experts at the SBM, immediate breast reconstruction procedure improves the oncological and aesthetic results of breast cancer ${ }^{7}$. Although there is consensus among the experts that there is no need for specific training for professionals to carry out these procedures, they consider the training of breast cancer specialists on all reconstructive techniques to be quite important?

On the one hand, there is the perception that, every year, the incidence rate of breast cancer diagnoses increases. On the other hand, there is the possibility that improved surgical techniques can carry out the treatment more safely and with minimal aesthetic and functional damages ${ }^{15}$. Thus, a model that can be followed is urgently needed, so that cancer treatment safety is aligned with aesthetic and functional results, and so that these women can have a better quality of life. "Surgeons must be attentive, trained, and dedicated to perfection ${ }^{8}$."

The training in Oncoplastic Surgery is established at the following competence levels:

- Level I: Unilateral treatment with tissue mobilization;

- Level II: Bilateral treatment with breast reduction, mastopexy and reconstruction of the areola and nipple;

- Level III: Immediate reconstruction of the breast, with expanders or prosthesis and contralateral symmetrization;
- Level IV: Reconstruction with autologous flaps ${ }^{16}$.

The professional development allows for a paradigm shift in the treatment of cancer patients. Also, when exploring how surgical breast reconstruction activities develop after the course, breast cancer is part of the professionals' responsibility toward social health.

It is believed that a more intense training of professionals in this type of procedure is necessary, both for the graduates of the residency programs in addition to those that have not yet had the possibility to develop the techniques in a systematic training. Continued improvement in this area may result in safer reconstructive activities that provide patients with cancer treatment associated with breast reconstruction - even in more complex cases, with recto-abdominal or large-dorsal flaps, for example.

Similarly to the specialists ${ }^{5}$, it is expected that each of the practitioners who have completed the SCBH course become a multiplier of the improved knowledge. This, ideally, will generate further improvement both in breast reconstruction rates in Brazil and in the quality of life of patients with breast cancer.

\section{RESULTS}

Data were collected from January to May of 2016 from a total of twenty respondents. This data is presented in Appendix 2 .

The answers obtained from the survey were analyzed and placed in graphs to better visualize them. Qualitative variables resulted in attributes or qualities (gender, work motivation, concept learning, for example). The quantitative variables resulted in numbers of certain scales.

The proposed classification of the competence levels ${ }^{16}$ guide the breast reconstruction activities of the professionals investigated. Before taking the course at SCBH:

- $\quad 76.5 \%$ performed Level I techniques;

- $\quad 5.9 \%$ performed Level II techniques;

- $23.5 \%$ performed Level III techniques;

- $\quad 11.8 \%$ performed Level IV techniques.

After the course, there was an increase in competence in the breast reconstructive activities of these professionals, as follows:

- $95 \%$ were now able to perform Level I techniques;

- $\quad 75 \%$ were now able to perform Level II techniques;

- $80 \%$ were now able to perform Level III techniques;

- $\quad 40 \%$ were now able to perform Level IV techniques.

Consequently, there is the possibility that the final result of the survey can act as a guide for the institution and for future professionals, who will benefit from the information regarding the professional and scientific potential of Oncoplastic Surgery Professional Development and Reconstructive Breast Care. 


\section{CONCLUSION}

The purpose of this study is to investigate the applicability of the systematization for the professional development of breast cancer specialists who completed the SCBH Course in the period from 2012 to 2014.

Based on the results obtained, it can be concluded that the course for the Professional Development of Breast Cancer

\section{REFERENCES}

1. Organização Mundial da Saúde. [Internet]. [cited on Feb. 2015]. Available from: http://www.who.int/eportuguese/ publications/pt

2. Sociedade Brasileira de Mastologia. [Internet]. [cited on Apr. 2015].Available from:http://www.sbmastologia.com.br/index/ index.php/rastreamento-e-diagnostico/60-estatisticas-sobrecancer-de-mama-no-brasil

3. Ferraz MB. Tradução para o português e validação do questionário para avaliar a capacidade funcional "Stanford Health assessment questionnaire” [thesis]. São Paulo: Escola Paulista de Medicina, Universidade Federal de São Paulo; 1990.

4. Brasil. Senado. Lei obriga reconstrução de mama [Internet]. 2013 [cited on 15 May. 2016]. Available from: http://wwwl2. senado.gov.br/jornal/edicoes/2013/05/07/lei-obrigareconstrucao-de-mama

5. Instituto Nacional de Câncer José Alencar Gomes da Silva. Novos construtores de autoestima. Rev Rede Câncer [Internet]. 2014 [cited on Nov. 2015];27:29-31. Available from: http:// www2.inca.gov.br/wps/wcm/connect/revistaredecancer/ site/home/n27/revista_27

6. Resende M de A. Reflexões oncoplásticas aos mastologistas brasileiros. Rev Bras Mastologia. 2012;22(11):1-2.

7. Urban C, Freitas Jr. R, Zucca-Matthes G, Blazús JVN, Brenelli FP, Pires DM, et al. Cirurgia Oncoplástica e Reconstrutiva da Mama: Reunião de Consenso da Sociedade Brasileira de Mastologia. Rev Bras Mastologia. 2015;25(4):118-24. DOI: 10.5327/Z201500040002RBM

8. Hartt V. Em defesa da Oncoplástica [Internet]. 2016 [cited on May 2016]. Available from: http://www.onconews.com. $\mathrm{br} /$ site/noticias/noticias/entrevistas/612-em-defesa-daoncopl\%C3\%A1stica.html

9. Santa Casa de Misericórdia de Belo Horizonte [Internet]. [cited on May 2015]. Available from: http://www.santacasabh.org.br/
Specialists in Oncoplastic and Reconstructive Breast Surgery promoted by SCBH is a very valid way for the professionals being specialized to benefit in the reflection of their practices, They learn to systematize their knowledge and additionally become aware of the theories that justify their decisions and attitudes in the real context of work. Moreover, they rebuild the lives of women who have become fragile with the disease, explain and rebuild the secret and sacred stories of both professionals and patients, and, finally, share knowledge and practices for the psychological well-being and a better aualitv of life for those involved.

inscricoes/registros/index/cirurgia-oncoplastica-da-mamahands-on-1.html\#.VkubI_mrSUk

10. PaulinelliRR, Ribeiro LFJ, Moura FilhoJWCM,Urban CA, Freitas Jr. R. Resultados do Programa de Educação Continuada em Oncoplastia e Reconstrução Mamária da Sociedade Brasileira de Mastologia no Hospital Araújo Jorge em Goiânia. Rev Bras Mastologia [Internet]. 2016 [cited on Nov. 2015];26(4):146-52. Available from: http://www.rbmastologia.com.br/wp-content/ uploads/2016/11/MAS-v26n4_146-152.pdf

DOI: $10.5327 / Z 201600040002 R B M$

11. Minayo MCS. O desafio do conhecimento científico: pesquisa qualitativa em saúde. $2^{\text {a }}$ ed. São Paulo: Hucitec-Abrasco; 1994.

12. Fontanella BJB, Ricas J, Turato ER. Amostragem por saturação em pesquisas qualitativas em saúde: contribuições teóricas. Cad Saúde Pública. 2008;24(1):17-27. http://dx.doi.org/10.1590/ S0102-311X2008000100003

13. Moscarola J. Enquêtes et analyse de données. Paris: Vuibert; 1990.

14. Instituto Nacional do Câncer José Alencar Gomes da Silva [Internet]. [cited on Nov. 2015]. Available from: http://www2. inca.gov.br/wps/wcm/connect/tiposdecancer/site/home/ mama/cancer_mama

14. Mizukami MGN, Reali AMMR, Reyes CR, Martucci EM, Lima EF, Trancredi RMSP, et al. Escola e aprendizagem da docência: processos de investigação e formação. São Carlos: EdUFSCar; 2002.

15. Instituto Nacional do Câncer José Alencar Gomes da Silva. Mama [Internet]. [cited on Apr. 2015]. Available from: http:// www2.inca.gov.br/wps/wcm/connect/tiposdecancer/site/ home/mama/cancer_mama

16. Urban C, Rjetiens M, Hurley IIJ. Oncoplastic and reconstructive surgery: qualifications, limits and mentoring. In: Urban C, Rjetiens M, Eds.. Oncoplastic and reconstructive breast surgery. Italia: Springer-Verlag; 2013. p. 44. 
Appendix 1. Questions for professionals.

$$
\begin{array}{ll}
\text { Age: } & \\
\text { Sex: } & \square \text { Female } \\
& \square \text { Male }
\end{array}
$$

City and State of professional practice:

1. Your certification by specialty is:

Specialist Title (T), Residence (R) and/or Specialization (S)

$\begin{array}{lccc} & T & \mathrm{R} & \mathrm{S} \\ \text { General Surgery } & \square & \square & \square \\ \text { Oncology Surgery } & \square & \square & \square \\ \text { Plastic Surgery } & \square & \square & \square \\ \text { Gynecology and Obstetrics } & \square & \square & \square \\ \text { Mastology } & \square & \square & \square\end{array}$

2. In what specialties do you perform?
$\square$ General Surgery
$\square$ Oncology Surgery
$\square$ Plastic Surgery
$\square$ Gynecology and Obstetrics
$\square$ Mastology

3. Academic background, scientific production and qualifications:
$\square$ Master's degree
$\square$ Doctorate degree
$\square$ Professor
$\square$ Preceptor
4. How many new cases of cancer are treated annually by you in your service?
$\square$ Below 50
$\square$ From 50 to 100
$\square \quad$ From 100 to 200
$\square$ Above 200

5. Who performs breast reconstructions in your service?

$\square$ Mastologist.

$\square$ Mastologist and plastic surgeon.

$\square$ Plastic surgeon.

$\square$ We do not perform breast reconstructions.

6. Regarding immediate reconstructions in patients who undergo mastectomy in your service, identify the alternative that most adequately corresponds to your reality:

$\square$ Less than $10 \%$ of the mastectomized patients undergo immediate reconstruction.

$\square \quad 10$ to $20 \%$ of the mastectomized patients undergo immediate reconstruction.

$\square \quad 20$ to $50 \%$ of the mastectomized patients undergo immediate reconstruction.

$\square$ More than $50 \%$ of the mastectomized patients undergo immediate reconstruction.

7. In relation to your training in Oncoplastic and Reconstructive Surgery, identify the alternative that most adequately corresponds to your reality:

$\square \quad$ I do not perform any form of oncoplastic and breast reconstruction surgery.

$\square$ I perform oncoplastic and breast reconstruction surgery together with another mastologist.

$\square$ I perform oncoplastic and breast reconstruction surgery together with a plastic surgeon.

$\square \quad$ I refer the patient to oncoplastic and breast reconstruction surgery at a later time.

$\square$ I perform oncoplastic and breast reconstruction surgery in all cases.

$\square$ I perform oncoplastic and breast reconstruction surgery in some cases.

8. How are immediate post-mastectomy reconstructions performed in your service?

$\square$ Predominantly with expanders and prostheses.

$\square$ Predominantly with pedicled autologous flaps.

$\square$ Predominantly with microsurgical flaps.

9. Regarding aesthetic and functional breast surgeries in non-cancer patients, identify the alternative that most adequately corresponds to your reality:

$\square$ I perform reduction surgeries, mastopexy and augmentation mammoplasty.

$\square$ I do not perform such surgeries. 
Appendix 1. Continuation.

10. At the beginning of the course, what was your reality?

$\square$ Able to perform partial reconstructions with oncoplastic techniques.

$\square$ Able to perform reconstructions with expanders and prostheses.

$\square$ Able to perform reconstructions with latissimus dorsi muscle.

$\square$ Able to perform reconstructions with TRAM.

$\square$ Able to perform breast reduction surgeries.

$\square$ Able to perform breast augmentation surgeries.

11. At the end of this course, what is your reality?

$\square$ I am able to perform partial reconstructions with oncoplastic techniques.

$\square \quad$ I am able to perform reconstructions with expanders and prostheses.

$\square$ I am able to perform reconstructions with latissimus dorsi muscle.

$\square$ I am able to perform reconstructions with TRAM.

$\square \quad$ I am able to perform reductive mastoplasty surgeries.

$\square$ I am able to perform augmentative mastoplasty surgeries.

Appendix 2. Responses from professionals.

Professionals who answered the questions: 20

Age: between 33 and 73 .

Sex: 7 women (35\%) and 13 men (65\%)

States of practice: MA, CE, PI, PE, MG, PR, SC, TO, GO and MT

Question 1 - Certification by field

$$
\begin{array}{r|l}
\text { General Surgery T } & 0(0 \%) \\
\text { General Surgery R } & 0(0 \%) \\
\text { General Surgery S } & 0(0 \%) \\
\text { Oncology Surgery T } & 2(10 \%) \\
\text { Oncology Surgery R } & 2(10 \%) \\
\text { Oncology Surgery S } & 1(5 \%) \\
\text { Plastic Surgery T } & 0(0 \%) \\
\text { Plastic Surgery R } & 0(0 \%) \\
\text { Plastic Surgery S } & 0(0 \%)
\end{array}
$$

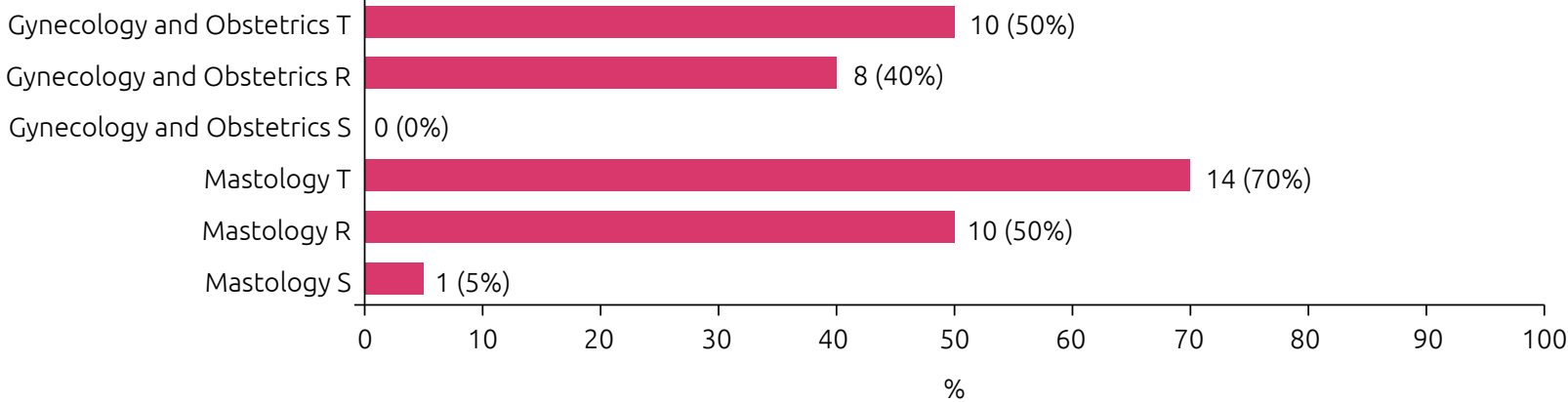

Question 2 - Field of practice of the professionals

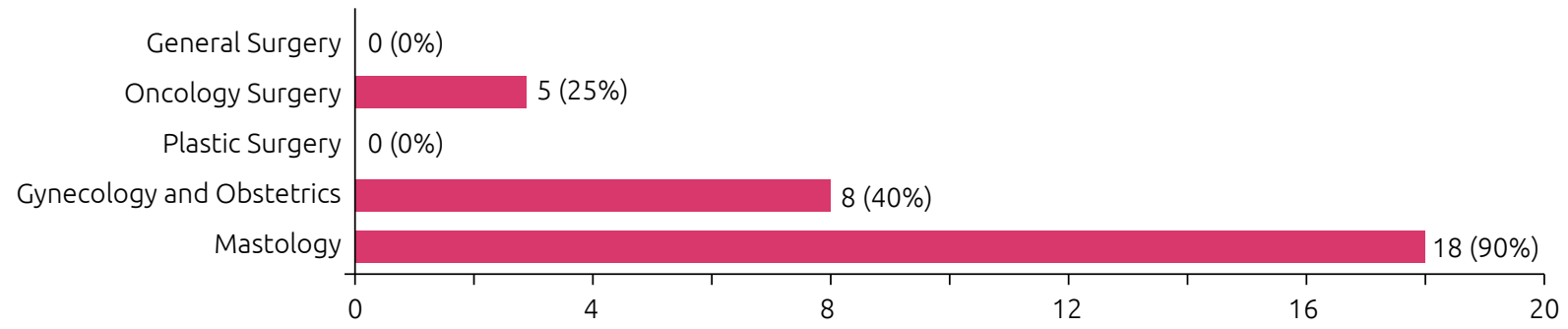


Appendix 2. Continuation.

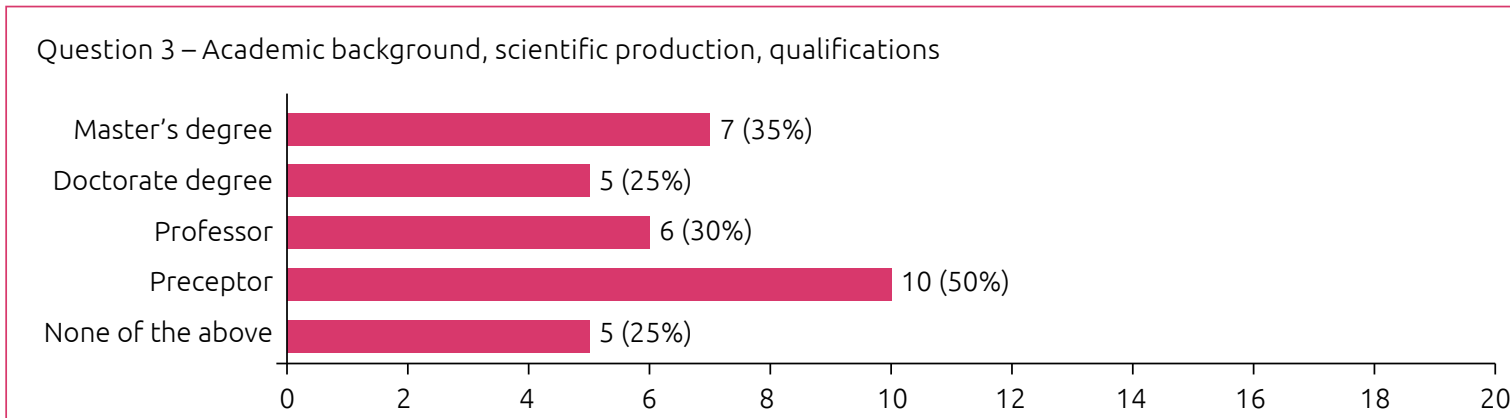

Question 4 - New cases of cancer treated annually by the professional in the service

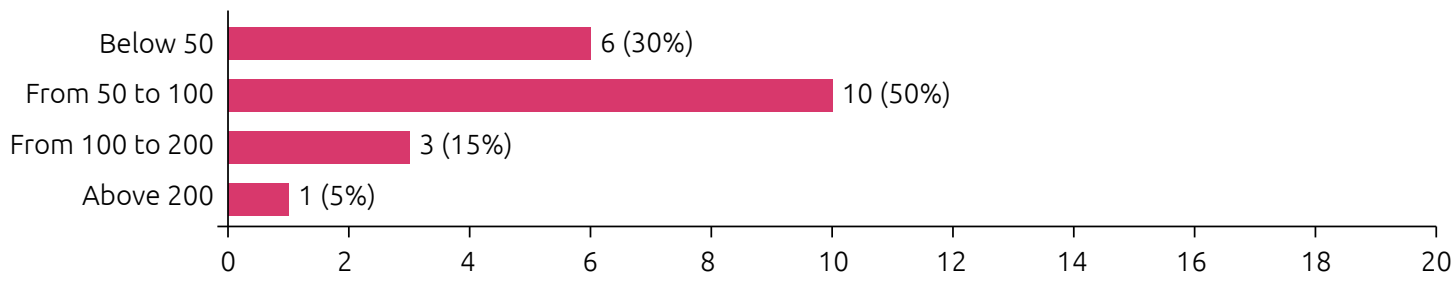

Question 5 - Who performs breast reconstructions in the respondent's service?

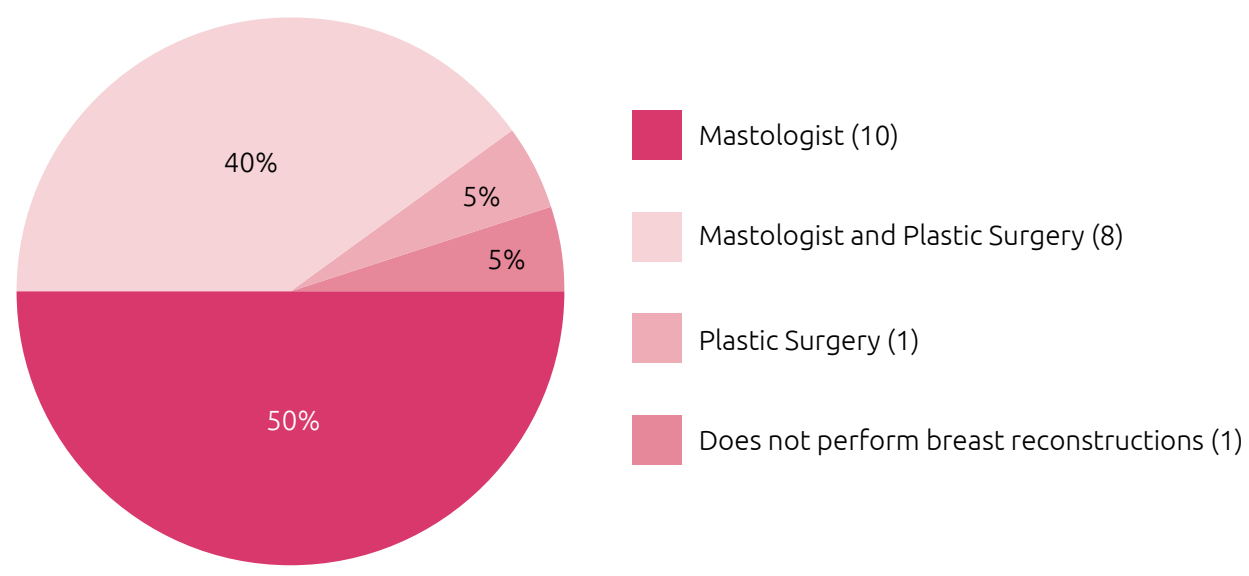

Question 6-Regarding immediate reconstructions in patients who undergo mastectomy in your service, identify the alternative that most adequately corresponds to your reality:

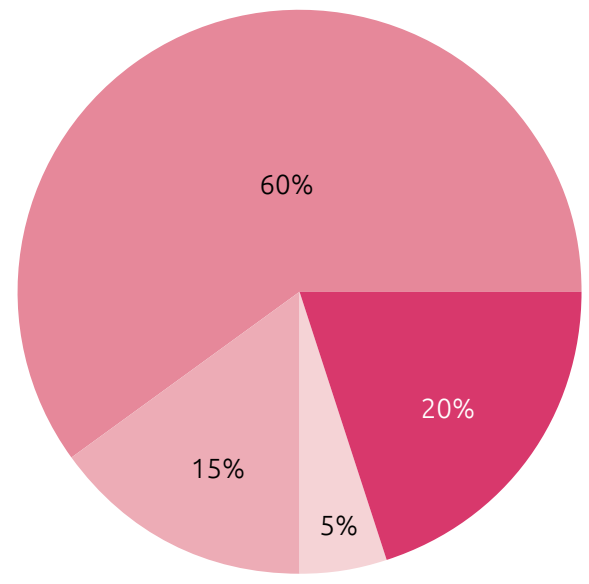

Less than $10 \%$ of the mastectomized patients

undergo immediate reconstruction (4)

10 to $20 \%$ of the mastectomized patients undergo immediate reconstruction (1)

20 to $50 \%$ of the mastectomized patients undergo immediate reconstruction (3)

More than $50 \%$ mastectomized patients undergo immediate reconstruction (12) 
Appendix 2. Continuation.

Question 7 - In relation to your training in Oncoplastic and Reconstructive Surgery, identify the alternative that most adequately corresponds to your reality:

I do not perform any form of oncoplastic and breast reconstruction surgery

I perform oncoplastic and breast reconstruction surgery together with another mastologist

I perform oncoplastic and breast reconstruction surgery together with a plastic surgeon

I refer the patient to oncoplastic and breast reconstruction surgery at a later time

I perform oncoplastic and breast reconstruction surgery in all cases

$1(5 \%)$

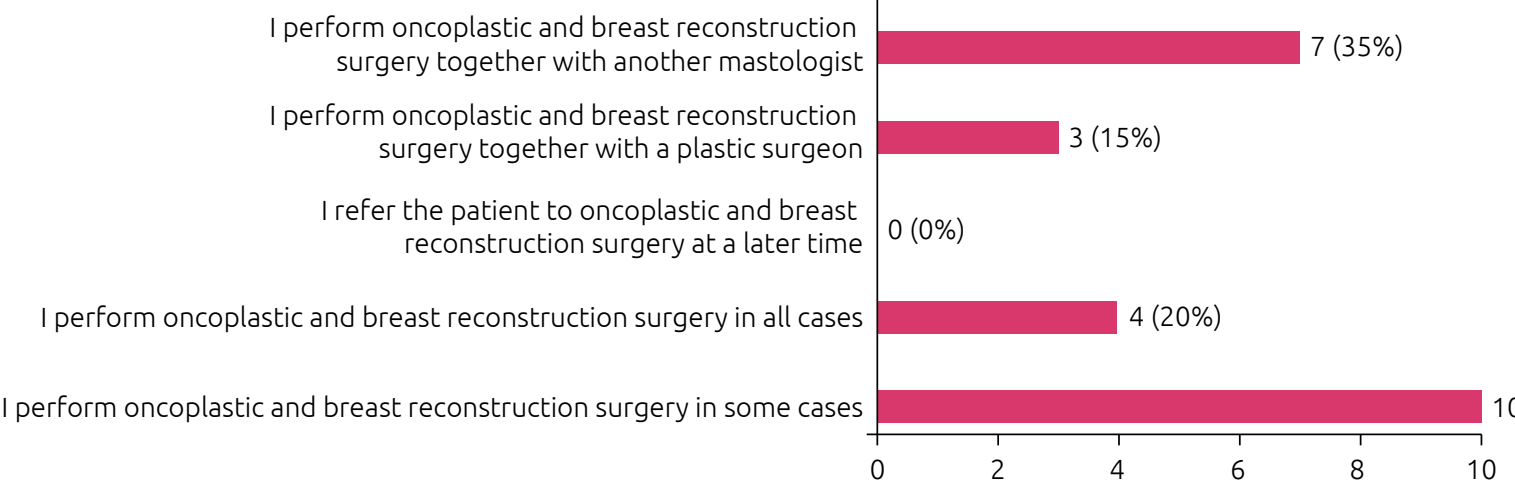

Question 8 - How are immediate post-mastectomy reconstructions performed in your service?

Predominantly with expanders and prostheses

Predominantly with pedicled autologous flaps

Predominantly with microsurgical flaps

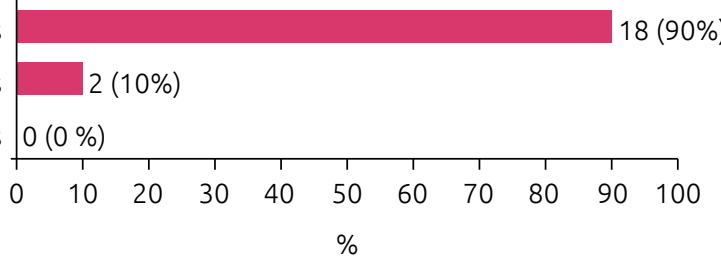

Question 9 - Regarding aesthetic and functional breast surgeries in non-cancer patients, identify the alternative that most adequately corresponds to your reality:

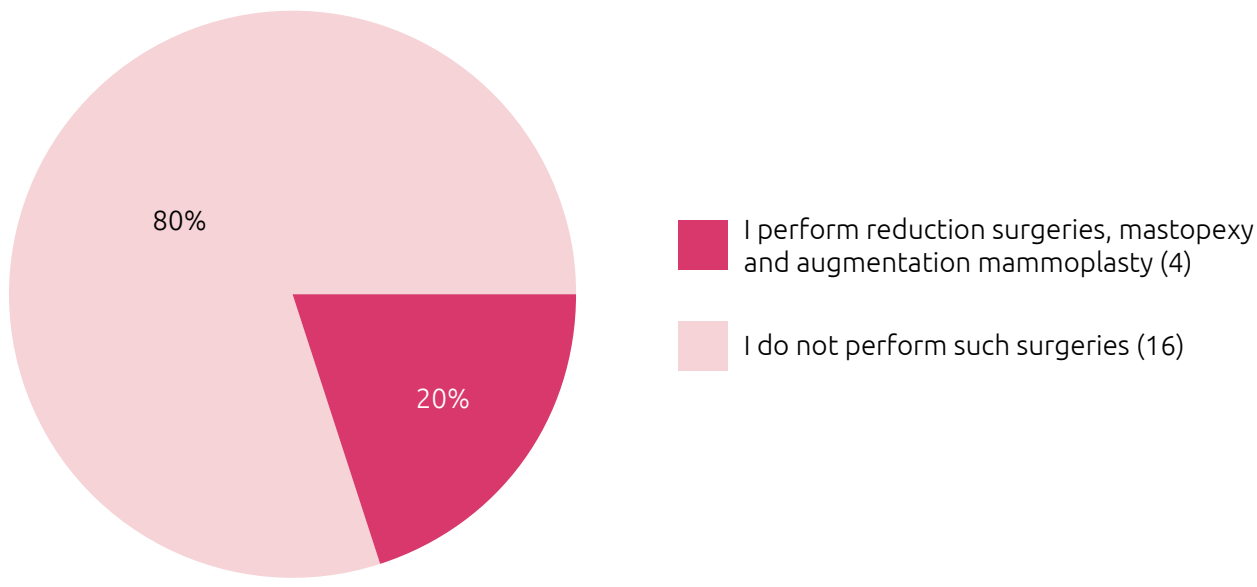

Question 10 - At the beginning of the course, the professionals were able to perform:

Partial reconstructions with oncoplastic techniques

Reconstructions with expanders and prostheses

Reconstructions with latissimus dorsi muscle

Reconstructions with TRAM

Breast reduction surgeries

Breast augmentation surgeries

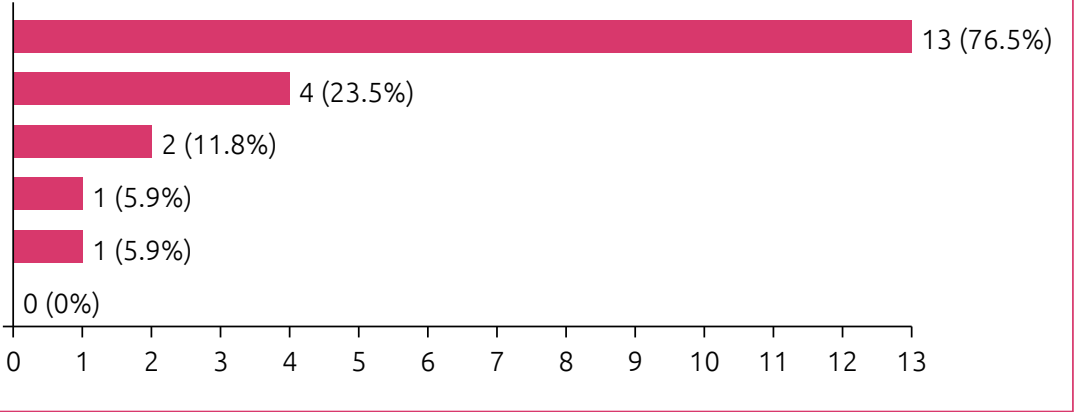


Appendix 2. Continuation.

Question 11 - At the end of this course, the reality of the professionals is:

Able to perform partial reconstructions with oncoplastic techniques Able to perform reconstructions with expanders and prostheses Able to perform reconstructions with latissimus dorsi muscle Able to perform reconstructions with TRAM Able to perform reductive mastoplasty surgeries Able to perform augmentative mastoplasty surgeries

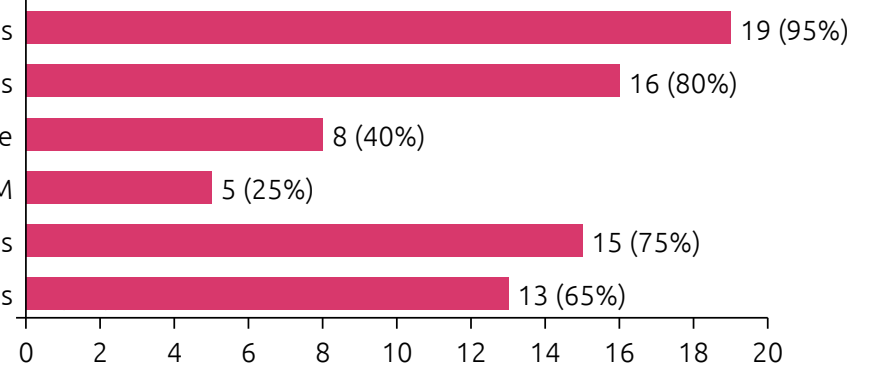

